Finanse, Rynki Finansowe, Ubezpieczenia nr 4/2018 (94), cz. 1

DOI: $10.18276 /$ frfu.2018.94/1-32

s. $367-375$

\title{
Legal regulations of internal audit in Poland
}

\author{
Kazimiera Winiarska*
}

\begin{abstract}
Purpose - In the paper legal regulations regarding internal audit in Poland are presented. Design/methodology/approach - The research involved the analysis of legal regulations on the subject of internal audit in the public sector.

Findings - The overview of the legal regulations of internal audit in Poland reveals that they refer solely to the public sector.

Originality/value - It is pointed out that there is a need for development of internal audit recommendations for other sectors of the economy.
\end{abstract}

Keywords: internal audit, public sector, audit plan, audit report

\section{Introduction}

Internal audit has a relatively short history in Poland (dating back to 2002) and is associated exclusively with the public sector. Across the world, on the other hand, internal audit has been known for centuries and it is present in all the major sectors of the economy. In order to capture the current state of the global internal audit the Institute of Internal Auditors (IIA) conducted two surveys - in 2006 and 2010 - covering various regions of the world and sectors of the economy (Alkafaji, Hussain, Khallaf, Majdalawieh, 2010). In Poland, many studies have been written on the subject in question (Kiziukiewicz, 2009, 2012; Moeller, 2011).

Introduction of internal audit in Poland was related to the country's accession to the European Union, which offered new funding opportunities promoting equal economic growth across the EU. The European Union imposed a condition requiring internal audit mechanisms to be implemented in order to monitor how the funds granted under operational programmes were spent.

The aim of the paper is to present current legal regulations on internal audit in Poland to a foreign reader. It is to make it easier to compare the subject and the object of scientific research within the issue in question in Poland. Internal audit regulations in Poland comply with international standards, however, they only apply to the public sector.

The analysis of Polish and foreign literature as well as legal regulations was conducted for this study, focusing on legal norms and international publications investigating the state of internal audit in the world.

* prof. zw. dr hab. Kazimiera Winiarska, University of Szczecin, Faculty of Economics and Management, Accounting Institute, e-mail: kr234@wneiz.pl. 


\section{Legal regulations of internal audit in Poland in the public sector}

Polish government decided to limit the introduction of internal audit to the public sector alone and defined the term in the Public Finance Law. Pursuant to article 274 of this act, internal audit is conducted in entities shown in Figure 1.

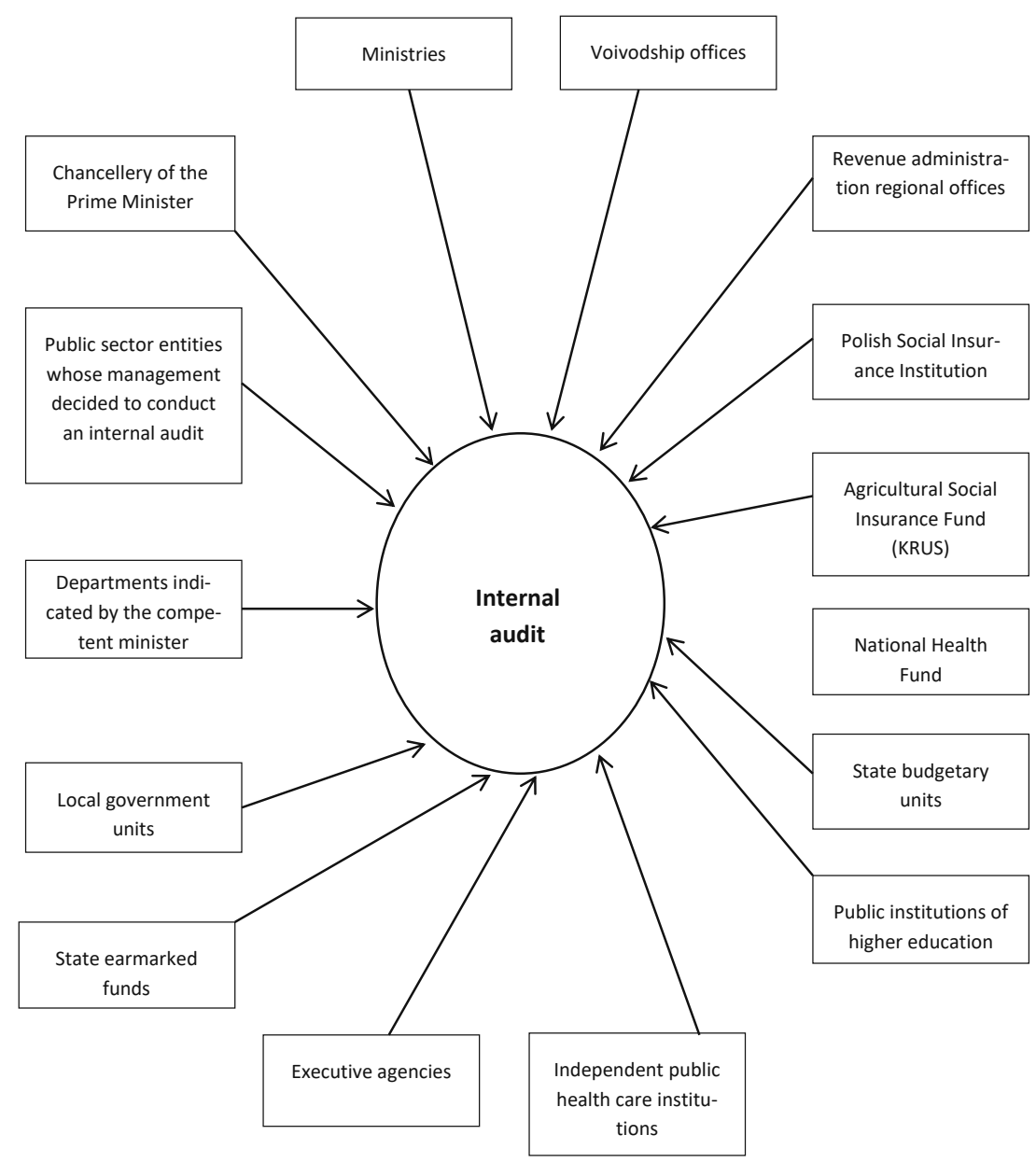

Figure 1. Entities obliged to introduce internal audit

Source: Winiarska (2017), p. 106.

Internal audit is also carried out in other public sector entities, including local government units, if they accumulate or spend significant amounts of public resources. The Minister of Finance by means of a regulation has determined the annual income and expenditure thresholds for internal audit. This amount has been set at PLN 40 million. 
The following regulations and announcements were issued based on the Public Finance Law:

1. Regulation of the Minister of Finance of 4 September 2015 on internal audit and information about the work and results of the audit.

2. Announcement of the Minister of Development and Finance of 12 December 2016 on internal audit standards for public sector entities.

3. Regulation of the Minister of Finance of 29 December 2009 on audit committee.

4. Announcement of the Minister of Finance of 7 November 2017 on the standard information about performance of internal audit activity.

The Regulation of the Minister of Finance of 4 September 2015 on internal audit and information about the work and results of the audit specifies:

- how to document the results of an internal audit,

- how to plan an internal audit engagement,

- how to perform an internal audit engagement and how to organise the collaboration between the auditor and staff of the department under review,

- how to prepare an internal audit report and what its components are.

Performance of an internal audit engagement is preceded by development of an internal audit plan, based on assessment of major risk areas related to the operations of the organisation. Risk assessment includes:

- the organisation's objectives and goals,

- legal regulations related to the organisation's activity,

- results of past audits,

- results of previous analyses of adequacy, effectiveness and efficiency of control systems, including internal control,

- internal and external risk factors affecting achievement of the organisation's objectives,

- comments of the employees of the organisation,

- number, type and size of financial operations,

- availability of foreign non-repayable funding with focus on the funder's requirements,

- number and qualifications of the organisation's employees,

- financial report and budget performance report.

Risk areas should be documented and ranked in order of importance for internal audit purposes; organisational factors should also be taken into account, e.g. time required to complete the audit engagement, training of the staff involved in the audit, the organisation of human resources and tangible assets, estimated costs of the audit and extra time allowed for unexpected activities. 


\section{Development of an internal audit plan}

Based on the accepted hierarchy of risk areas, an audit plan is developed. The audit plan for the coming year is developed by the chief audit executive in agreement with the head of the organisation. If in the course of his or her activity, the internal auditor reaches a conclusion that performance of all the audit engagements defined in the plan is either unfeasible or useless, both parties revise the original audit plan and make necessary changes in writing. At the request of the head of the organisation, or on an unsolicited basis, the internal auditor may perform an ad hoc internal audit engagement. If such an additional audit engagement poses a threat to the execution of the audit plan, the auditor communicates this fact (in writing) to the head of the organisation.

An audit plan describes:

- areas of the operations of the organisation where assurance engagements will be performed in a given year,

- the time budget of the internal audit department in a given year expressed in mandays, including in particular the amount of time allocated to:

a) performance of individual assurance engagements,

b) providing consulting services,

c) monitoring implementation of the recommendations and verification activities,

d) continuation of audit engagements from the previous year.

The audit plan is signed by the chief audit executive and the head of the organisation. Any changes to the audit plan require written consent of two parties.

If no audit plan has been developed for a given year, the chief audit executive immediately develops an audit plan for that year or - where justified - in agreement with the head of the organisation develops a schedule of individual audit engagements to be performed by the end of the year. The audit plan is executed through completion of individual audit engagements.

Before starting an assurance engagement, the internal auditor performs a review which includes in particular:

- identification of the organisation's objectives and scope of activity under review,

- risk assessment taking into account the existing controls,

- the agreed criteria of controls evaluation in the organisation's activity under review: if no such agreement can be reached with the auditee, the criteria are agreed on with the head of the organisation.

When starting the actual engagement, the auditor organises an opening session inviting all the internal auditors involved and the head of the department under review or a designated employee. During the opening session, the internal auditor presents the objectives, scope and organisational principles of the engagement. The head of the department under review presents basic information about the department's activity and both parties make necessary arrangements to minimise work disruption during the audit engagement. During the engagement, the internal auditor may request additional meetings with the head of the department under review or its employees. 
Having completed the review, the internal auditor develops an assurance engagement work program which includes among others:

- results of the initial review,

- comments of the head of the organisation and the auditee,

- resources needed to complete the engagement, including assistance of an expert,

- expected duration of the audit engagement.

The work program should include several elements, as specified in Table 1.

Table 1

Elements of an audit engagement work program

\begin{tabular}{ll}
\hline No. & Specification \\
\hline 1. & Definition of the engagement, including its title. \\
\hline 2. & Objectives of the engagement. \\
\hline 3. & Subject and object of the engagement. \\
\hline 4. & $\begin{array}{l}\text { Methodological guidelines, including: } \\
\text { a) audit techniques to be employed, } \\
\text { b) specific problems (significant risks) requiring special attention, } \\
\text { c) type of evidence which needs to be collected and methods of its examination. }\end{array}$ \\
\hline 5. & Organisational principles and schedule of activities. \\
\hline
\end{tabular}

Source: own study.

Where justified, the internal auditor may make changes to the work program in the course of the assurance engagement. Any changes to the work program should be made in writing. The assurance engagement work program and its changes require approval by the chief audit executive.

\section{Development of an assurance engagement report}

Upon completion of the engagement, in order to present its initial results the internal auditor organises a closing session with the head of the department under review. Other people may also participate in this meeting, namely supervisors of the department under review, designated employees of that department and the chief audit executive.

The internal auditor takes the minutes during all sessions, including the opening and closing sessions, specifying in particular the objective, course and results of the meeting. The minutes are signed by the internal auditor chairing the session and the head of the department under review or a designated employee. Should the latter refuse to sign the minutes, the auditor makes an appropriate comment in the minutes, whereas the person who refused to sign the document should immediately provide their reasons for doing so in writing. 
If no agreement can be reached on the initial results of the internal audit, the auditee can submit his or her reservations in writing by the date appointed by the auditor, but no sooner than 7 days after the initial results were communicated to the auditee.

When the initial results of the internal audit are agreed on or reservations are received, the internal auditor prepares an assurance engagement report containing in particular:

- title and objective of the engagement,

- subject and object of the engagement,

- starting date,

- definition and assessment according to the criteria defined in the engagement work program,

- recommendations,

- internal auditor's comments to any reservations,

- general evaluation of the adequacy, effectiveness and efficiency of internal control over the area of activity under review,

- report date,

- name and signature of the internal auditor performing the engagement.

If the assurance engagement is a joint effort of several internal auditors, the report may be signed either by all the auditors involved or the auditor supervising the engagement, appointed by the chief audit executive from among all the auditors involved in that engagement. The report should be clear, concise, transparent, objective and complete.

The internal auditor submits the report to the head of the department under review. The auditee determines how the recommendations will be implemented no later than 14 days after receiving the engagement report. Where justified, the internal auditor may submit to the head of the department only excerpts of the report which concern the activity of that department. If the auditee refuses to implement the recommendations, he or she can submit - in writing additional explanations or justified reservations about the contents of the report by a date appointed by the internal auditor but no sooner than 7 days after receiving the report. Those explanations or reservations are next analysed by the internal auditor who, if appropriate, initiates a discovery process. If the explanations or reservations are found valid, the internal auditor submits (in writing) to the head of the department under review his or her opinion and reasons for this opinion.

After examining any additional explanations or reservations, the internal auditor submits one copy of the report to the head of the organisation and one copy to the head of the department under review. The head of the organisation should take corrective action to remove the deficiencies or introduce improvements, appoint employees responsible for implementing the recommendations outlined in the report and set a deadline for their implementation, informing the internal auditor about it.

To evaluate the organisation's corrective action taken to implement the recommendations outlined in the report, the internal auditor can undertake verification activities, which he or she describes in a separate note. The note is handed both to the head of the organisation and the head of the department under review. 
The order of audit activities as outlined in the aforementioned regulation is shown in Figure 2.

The internal auditor provides consulting services upon request of the head of the organisation where he or she is employed. As a result of those activities, the auditor may produce an opinion or recommendations for improvements in the organisation's activity. The auditor can communicate, on an unsolicited basis, the conclusions aimed at improving the organisation's performance to either the head of the organisation or the head of the department under review.

The objectives and scope of consulting services should be documented by the internal auditor. The form and contents of the report on consulting services should be tailored to the type and character of the engagement. Neither the head of the organisation nor the head of the department are bound by conclusions, recommendations or opinions issued by the internal auditor.

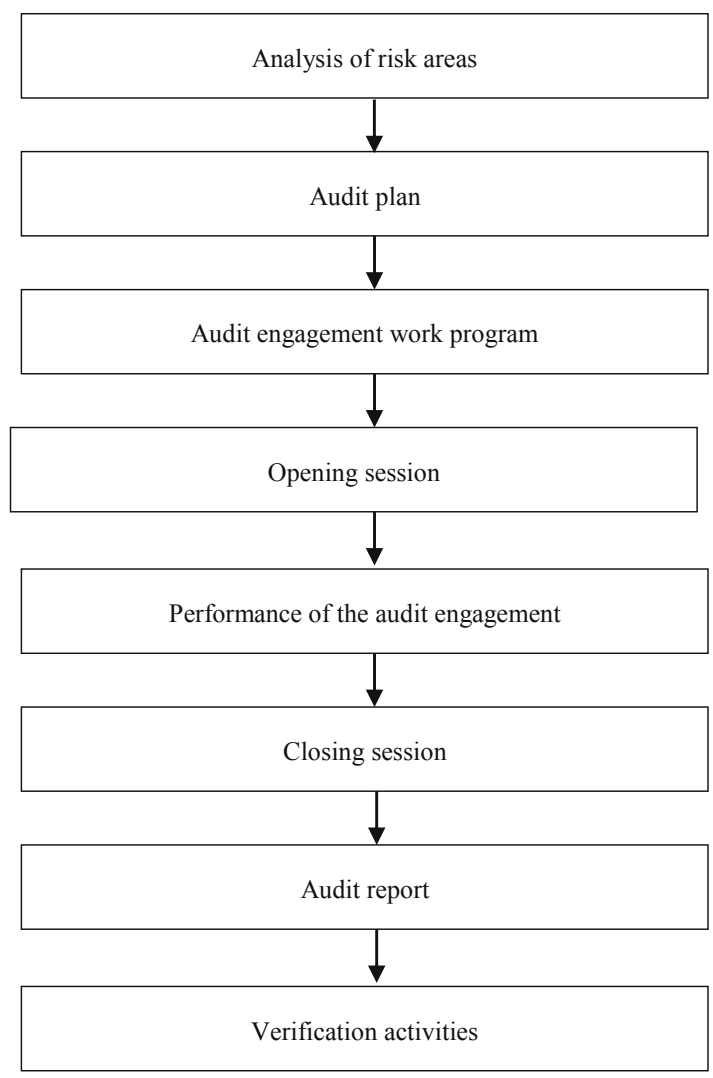

Figure 2. Order of audit activities Source: own study. 
By the end of January each year the internal auditor should prepare an audit performance report for the previous year and submit it to the head of the organisation.

The chief audit executive in a public sector entity submits a copy of the report to an internal audit department in the competent ministry by 15 February each year.

An efficient internal audit department should operate based on internal regulations which, apart from definitions of the basic terms, principles and objectives of audit activity, should also describe individual audit engagements, rights and obligations of the auditor and the auditee, rules for reporting, as well as the place of the internal audit department in the organisational structure.

\section{Conclusions}

Definitions and interpretations of internal audit are in compliance with the international standards for internal auditing which have been translated into Polish.

Apart from the public sector, internal audit in Poland is also carried out - among others in agriculture, banking, insurance, multinational corporations and listed companies. Guidelines as to the organisation of internal audit and its objectives are regulated separately by each entity based on international standards. Internal audit charters, which define the rights and obligations of both the department under review and the auditor, play a role of internal audit rules of conduct.

Foreign literature focuses on the presentation of the use of internal audit in all sectors of the economy. In Poland an examination of listed companies is an attempt at extending the scope of audit. Legal regulations on the subject of internal audit for entities outside the public sector concern audit committees only. The limited resources in economy may contribute to extending the obligatory use of internal audit in the future.

\section{References}

Act of 27 August 2009 - Public Finance Law. Journal of Laws of 2016, item 1870 as amended.

Alkafaji, Y., Hussain, S., Khallaf, A., Majdalawieh, M.A. (2010). Characteristics of an Internal Audit Activity. Report I. Altamonte Springs: Institute of Internal Auditors.

Announcement of the Minister of Development and Finance of 12 December 2016 on Internal Audit Standards for Public Sector Entities. Journal of the Minister of Development and Finance, item 28.

Announcement of the Minister of Finance of 7 November 2017 on the Standard Information about Performance of Internal Audit Activity. Journal of the Minister of Finance, item 220.

Kiziukiewicz, T. (ed.) (2009). Audyt wewnętrzny w jednostkach sektora finansów publicznych. Warsaw: Difin.

Kiziukiewicz, T. (ed.) (2012). Zasady audytu wewnętrznego w sektorze finansów publicznych wedtug najnowszej wersji ustawy o finansach publicznych. Warsaw: Difin.

Moeller, R. (2011). Nowoczesny audyt wewnętrzny. Warsaw: Wolters Kluwer.

Regulation of the Minister of Finance of 29 December 2009 on Audit Committee. Journal of Laws of 2016, item 2049. 
Regulation of the Minister of Finance of 4 September 2015 on Internal Audit and Information about the Work and Results of the Audit. Journal of Laws, item 1480 as amended.

Winiarska, K. (2017). Audyt wewnętrzny. Teoria i zastosowanie. Warsaw: Wolters Kluwer.

\section{REGULACJE PRAWNE AUDYTU WEWNĘTRZNEGO W POLSCE}

Streszczenie: $\mathrm{Cel}-\mathrm{W}$ artykule zaprezentowano opublikowane akty prawne regulujące audyt wewnętrzny w Polsce.

Metodologia badania - Badania polegały na analizie regulacji prawnych w zakresie audytu wewnętrznego w sektorze finansów publicznych.

Wynik - Z przeglądu regulacji prawnych audytu wewnętrznego w Polsce wynika, że dotyczą one wyłącznie sektora finansów publicznych.

Oryginalnośćlwartość - Zwrócono uwagę na potrzebę opracowania rekomendacji w sprawie audytu wewnętrznego w pozostałych sektorach gospodarki.

Słowa kluczowe: audyt wewnętrzny, sektor finansów publicznych, plan audytu, sprawozdanie z wykonania zadania audytowego

\section{Citation}

Winiarska, K. (2018). Legal regulations of internal audit in Poland. Finanse, Rynki Finansowe, Ubezpieczenia, 4 (94/1), 367-375. DOI: 10.18276/frfu.2018.94/1-32. 